\title{
Efficacy of Ethanol Extract from Leaves Of Malva parviflora to Inhibit Bacterial Biofilm Formation
}

\author{
Marwa Fady Abozed ${ }^{1,2}$, Nadia Hashish ${ }^{3,4} \&$ Magda Gazer ${ }^{5}$ \\ ${ }^{1}$ Department of Microbiology and Immunology, Faculty of Pharmacy \& Dentistry, Buraydah Private College, \\ Saudi Arabia \\ ${ }^{2}$ Infection Control Unit, Zagazig University Hopsitals, Egypt \\ ${ }^{3}$ Department of Medicinal Chemistry \& Pharmacogonosy, Faculty of Pharmacy, Qassim University, Saudi Arabia \\ ${ }^{4}$ Department of Pharmacogonosy, Faculty of Pharmacy, Mansoura University, Egypt \\ ${ }^{5}$ Department of Biology, Faculty of Science and Art, Qassim University, Saudi Arabia \\ Correspondence: Marwa Fady Abozed, Department of Microbiology and Immunology, Faculty of Pharmacy \& \\ Dentistry, Buraydah Private College, Saudi Arabia. \\ E-mail: Marwa.Fadi@bpc.edu.sa/marwafady1977@gmail.com
}

Received: March 28, 2018

Accepted: April 8, 2018

Online Published: April 19, 2018

doi:10.5539/jmbr.v8n1p23

URL: https://doi.org/10.5539/jmbr.v8n1p23

\begin{abstract}
Infection due to bacterial biofilm represents a serious health threat worldwide mostly due to the appearance of antibiotic resistant strains. Treatment of bacterial biofilm infection is currently a difficult and complicated challenge for microbiologists and clinicians. Antibiotics treatment alone is often inadequate to overcome bacterial biofilm infection so the necessity of research for alternative to inhibit biofilm formation. The purpose of this study was to investigate the efficacy of leaves extract of Malva parviflora as antibiofilm against different pathogens .The plant extraction was done with ethanol under cold extraction. Antibiofilm effect was evaluated for Staphylococcus aureus, Klebsiella pneumonia and Escherichia coli using 96 wells technique. The results revealed that leaves extract of Malva parviflora had efficacy to eradicate bioflm formed from most of isolates.
\end{abstract}

Keywords: Biofilm, Malva parviflora, Anibiofilm, $\beta$-Sitosterol

\section{Introduction}

Biofilm is a structured consortium attached on a living or inert surface formed by microbial cells stuck to each other and is surrounded by the self-produced extracellular polymeric matrix. The formation of biofilm is considered an adaptation of microbes to hostile environments (De Fuente- Núñez et al., 2013; Hall-Stoodley et al., 2004). Biofilm-forming bacterial cells are significantly more resistant to antibiotics and host immune defense than their planktonic counterparts (Hengzhuang et al., 2011; Hengzhuang et al., 2012).

Aggressive and intensive antibiotic treatment is usually helpful to control the exacerbations of chronic biofilm infections induced by dispersed bacteria and reduce the biofilms, but cannot eradicate the biofilm infections (Høiby et al., 2010; Høiby, 2011), because the minimal concentration of antibiotic for eradication of mature biofilm is difficult to reach in vivo (Hengzhuang et al., 2011). Therefore, once a bacterial biofilm infection established, it becomes difficult to eradicate. Bacterial biofilm formation is widely found in natural environments with water and also in human diseases, especially in the patients with indwelling devices for the purpose of medical treatments (Hall-Stoodley et al., 2004; Høiby et al., 2010). The number of bacterial infections that involve biofilms varies depending on the reporting agency, with estimation being around $65 \%$ of all infections according to the Center for Disease Control (CDC), and 80\% according to the National Institutes of Health (NIH).

Bacterial biofilms are characterized as highly resistant to antibiotic treatment and immune responses (Høiby et al., 2010). Although it is well known that antibiotic treatment is currently most important and effective measure for the control of microbial infections, however, antibiotic treatments are almost impossible to eradicate biofilm infections. In vitro and in vivo experiments demonstrated that the minimum inhibitory concentration (MIC) and the minimum bactericidal concentration (MBC) for biofilm bacterial cells were usually much higher (approximately10-1000 times) than the planktonic bacterial cells (Hengzhuang et al., 2011; Høiby et al., 2011). 
The effective antibiotic MBC in vivo for biofilm eradication are therefore impossible to reach by conventional antibiotic administrations due to the toxicities and the side effects of antibiotics and the limitation of renal and hepatic functions. Treatment of biofilm infections becomes therefore challenging and attracts significantly scientific attention (Hong et al., 2014).

Ever since the advent of humanity on earth, plants have served as unlimited source of phytotherapeuticals for various diseases (Clardy \& Walsh, 2004). In recent years, the emergence of biofilm infections have generated an urgent alarm in research and development field in seeks for novel antimicrobials from ethnomedicinal plant (Perumal \& Mahmud, 2013).

Currently, there has been great interest in the search for non-lethal antibiofilm agents (Adesina et al., 2015).

Despite the various researches concerning the evaluation of multiple bioactivities of Malva parviflora, none has dealt with the bacterial biofilm inhibition by this plant. Therefore the aim of this study was to investigate the effect of Malva parviflora as an antibiofilm agent.

Malva is a widespread tropical and temperate genus of the family Malvaceae (Boulos, 2000). Plants of this family are well known for their antibacterial and antifungal activities due to the presence of alkaloids, essential oils and phenolic compunds (Abad et al., 2007). Malva parviflora has been widely used in many parts of the world for curing various diseases (Ododo et al., 2016).

This work aimed to screen effect of Malva parviflora extraction as antibiofilm against Staphylococcus aureus, Escherichia coli, Klebesilla pneumonia. To our knowledge, this is the first report regarding the use of this plant as antibiofilm.

\section{Methods}

\subsection{Collection of Plant Materials}

Fresh samples of Malva parviflora were collected and identified from Alrib'ania, AlQassim by Dr. Magda Gazer in January, 2015. The plant was identified and authenticated by Dr. Magda Gazer, College of Science and Art, Biology Department, Qassim University, Qassim , Saudi Arabia. (according to Chaudhary, 1999-2001 and Mighaid, 1996.) The leaves were air dried, powdered then stored in an air tight container for further analysis.

\subsection{Extraction}

Twenty grams of dry leaves of Malva parviflora was grinded into fine powder then extracted by decoction by boiling with ethanol for 5 minutes, followed by filtration and concentration of the filtrate and evaporated till dryness on water bath to afford one gram extract. For further use, the extract was stored in airtight container at $4^{\circ} \mathrm{C}$ in the refrigerator.

\subsection{Test Organisms}

The susceptibility test comprises a panel of clinically resistant Gram-negative and Gram-positive bacteria. These selected human pathogenic bacteria are capable of forming biofilms and causes severe infections. The panel of clinically resistant pathogens used in this study includes 40 isolates of Klebsiella pneumonia, Escherichia coli and Satphylococcus aureus. The clinical isolates were obtained from Clinical Laboratory Department of Al Fayha Clinic in Buraydah, Qassim, Saudi Arabia. The isolates were propagated on nutrient agar plates and maintained on the plate at $4^{\circ} \mathrm{C}$. The isolates were sub-cultured in nutrient agar at $37^{\circ} \mathrm{C}$ for $24 \mathrm{~h}$. prior to further studies.

\subsection{Inocula Preparation}

All bacterial strains were recovered on a fresh tryptic soy agar (Difco, USA) plate $24 \mathrm{~h}$ prior to antimicrobial test. To prepare the inoculum, colonies from fresh tryptic soy agar were transferred into sterile Mueller Hinton (MH) liquid growth medium and incubated at $37^{\circ} \mathrm{C}$ overnight. Aliquots $(500 \mu \mathrm{l})$ were transferred to $10 \mathrm{ml}$ of fresh $\mathrm{MH}$ broth and incubated at $37^{\circ} \mathrm{C}$. Cells were harvested by centrifugation $\left(3,000 \mathrm{~g}, 5 \mathrm{~min}\right.$ at $\left.4{ }^{\circ} \mathrm{C}\right)$, washed in $10 \mathrm{mmol} / \mathrm{L}$ phosphate-buffered saline (PBS) (pH 7.4), and re-suspended in MH broth to an approximate cell density of 1.0 $\times 10^{5} \mathrm{CFU} / \mathrm{ml}$. The final cells concentration was confirmed by viable counts.

\subsubsection{Minimum Inhibitory Concentration (MIC) and Minimum Bactericidal Concentration (MBC)}

The minimum inhibitory concentrations (MIC) of leaves extract of Malva. parviflora were determined by using assay of serial broth microdilution method by 96 well as described by (Eloff,1998). This assay was performed using flat-bottomed polystyrene96-well clear microtiter plates with standard plate layout as proposed by Cos et al. (2006). Briefly, ethanol extract of leaves of Malva parviflora was dissolved in DMSO and an identical two fold serial dilution using $\mathrm{MH}$ broth were made to form $31.25-1000 \mathrm{mg} / \mathrm{ml}$.One hundred microliters of bacterial 
inoculum was added and mixed thoroughly in all the wells $(15.625-500 \mathrm{mg} / \mathrm{ml})$ as the highest in-test concentration.

The microtiter plates were sealed with parafilm tape and incubated overnight at $37^{\circ} \mathrm{C}$. An appropriate mixture of solvent DMSO, medium and inoculum were included as drug-free control and the final concentration of DMSO in the well was ensured to be less than $1 \%(\mathrm{v} / \mathrm{v})$. An additional non-infected medium was included for sterility check. The MIC of leaves extract of Malva parviflora was determined by using recovery broth method according to Yue et al. (2009) and the least concentration inhibited the growth was determined.

For the determination of minimum bactericidal concentration (MBC), $20 \mu \mathrm{l}$ of culture medium from the microtiter plate wells that showed no growth of bacteria was re-inoculated on MH agar plates. After $24 \mathrm{~h}$ of incubation at 37 , MBCs were determined as the lowest concentration that yielded no bacterial growth on $\mathrm{MH}$ agar plates.

\subsection{Biofilm Formation}

The bacterial cells were grown in tryptic soy broth (TSB) at $37^{\circ} \mathrm{C}$ overnight. The cultures was then harvested by centrifugation $\left(14,000 \mathrm{rpm}, 15 \mathrm{~min}\right.$ at $4^{\circ} \mathrm{C}$ ) and rinsed with phosphate-buffered saline (PBS, pH 7.4). The washed bacterial cells were then resuspended in tryptic soy broth to approximately $1 \times 10^{7} \mathrm{cfu} / \mathrm{ml}$ (determined by plate count assay) $200 \mu \mathrm{l} /$ well of bacterial suspension was transferred to sterile 96 well microtiter plates for $24 \mathrm{~h}$. at $37^{\circ} \mathrm{C}$. After $24 \mathrm{~h}$ of biofilm formation the supernatant of each well was removed and washed twice with $200 \mu \mathrm{l}$ of sterilized water, biofilms formed in the inner surfaces of each well of the microtiter plates subsequently treated (Stepanovic et al., 2000).

\subsubsection{Biofilm Detection}

Biofilm mass of different isolates was detected by crystal violet (CV) staining method, adapted from (Stepanovic et al., 2000). For that, the microtiter plates containing the biofilms were left to air dry for $30 \mathrm{~min}$, and $200 \mu \mathrm{l}$ of $98 \%$ methanol were transferred to each well in order to fix the remaining attached cells, for $15 \mathrm{~min}$. Afterwards, the plates were emptied and left to air dry. The fixed cells were stained with $200 \mu \mathrm{L}$ of CV (Gram's staining; Merck) per well, for $5 \mathrm{~min}$. After this staining step, the plates were washed with running tap water, air dried and filled with $200 \mu \mathrm{l}$ of $33 \%(\mathrm{v} / \mathrm{v})$ of glacial acetic acid in order to resolubilize the CV bound to the adherent biofilm . After that, the quantitative analysis of biofilm mass was performed through the measure of optical density at $750 \mathrm{~nm}$ of each well using a microtiter plate reader.

\subsubsection{Inhibition of Biofilm Formation}

The effect of leaves extract of Malva parviflora to inhibit biofilm formation was measured using microplate based assay, modified from (Stepanovic et al., 20007). Briefly, the bacterial cells were grown in tryptic soy broth (TSB) at $37^{\circ} \mathrm{C}$ overnight. The cultures was then harvested by centrifugation $\left(14,000 \mathrm{rpm}, 15 \mathrm{~min}\right.$ at $\left.4^{\circ} \mathrm{C}\right)$ and rinsed with phosphate-buffered saline (PBS, pH 7.4). The washed bacterial cells were then resuspended in tryptic soy broth to approximately $1 \times 10^{7} \mathrm{cfu} / \mathrm{ml}$ (determined by plate count assay).

An amount of $100 \mu \mathrm{L}$ of the leaves extract of Malva parviflora solution was then pre-mixed with the bacterial inocula $(100 \mu \mathrm{L})$ to attain final concentration ranging from $125-1000 \mathrm{mg} / \mathrm{ml}$. One hundred microliters of this mixture for each concentration was added to three separate wells in the 96-wellmicroplates for replicate testing. Wells containing mixture of dilute DMSO and inoculum were included as control with DMSO final concentration of $1 \%(\mathrm{v} / \mathrm{v})$. After $24 \mathrm{~h}$ of incubation at $37^{\circ} \mathrm{C}$, the supernatant containing TSB and planktonic cells were gently removed from the microplate wells and the wells were washed twice with $150 \mu \mathrm{L}$ of PBS.

After rinsing, $100 \mu \mathrm{l}$ of TSB were added and the suspension was incubated for $24 \mathrm{~h}$ at $37^{\circ} \mathrm{C}$. The minimum biofilm inhibitory concentration (MBIC) is defined as the lowest concentration of an antimicrobial agent required to inhibit the formation of biofilms was determined by observing the growth of bacteria in the microplate wells.

\subsubsection{Eradication of Biofilms}

Biofilm bacterial culture was set up by a modification of an established method of (Deighton et al., 2001). Briefly, a bacterial suspension of McFarland $0.5(\sim 108 \mathrm{CFU} / \mathrm{ml})$ was diluted 1:100 into Trypticate Soya Broth (TSB). A hundred microliters of the diluted bacterial suspensions were pipetted into each well in a 96-well flat-bottom microplate and incubated for $18-24 \mathrm{~h}$ at $35^{\circ} \mathrm{C}$ without shaking. After overnight incubation, the bacterial suspensions were aspirated and the wells were rinsed twice with $100 \mu \mathrm{L}$ of phosphate buffer saline (PBS) per well to remove non adherent bacteria.

The biofilms established for 24 hours in the each well were subsequently treated with two-fold serial dilutions of leaves extract of Malva Parviflora extract $(2000 \mathrm{mg} / \mathrm{ml}$ as the highest in-test concentration). The microtiter plates were sealed with parafilm tape and incubated overnight at $37^{\circ} \mathrm{C}$. After overnight incubation, the suspensions were 
discarded and washed twice times with $100 \mu \mathrm{L}$ of PBS and new broth were added for another $24 \mathrm{~h}$. After $24 \mathrm{~h}$. incubation $150 \mu \mathrm{l}$ of the contents in each well of the microplate was serially diluted and plated onto solid media for viable count, this method is defined as the broth recovery method according to (Yue et al., 2009).

\subsection{Statistical Methods}

Data obtained were statistically analyzed using Analysis of Variance (ANOVA) Microsoft EXCEL 2010.

Table 1. Biological activity of ethanol extract of leaves of Malva parviflora $(\mathrm{mg} / \mathrm{ml})$ against resistant clinical isolates strains

\begin{tabular}{|c|c|c|c|c|}
\hline \multirow[t]{2}{*}{ Resistant clinical isolates } & \multicolumn{4}{|c|}{ Malva parvifloraethanol extract } \\
\hline & $\mathrm{MIC}(\mathrm{mg} / \mathrm{ml})$ & $\mathrm{MBC}(\mathrm{mg} / \mathrm{ml})$ & $\mathrm{MBIC}(\mathrm{mg} / \mathrm{ml})$ & $\operatorname{MBEC}(\mathrm{mg} / \mathrm{ml})$ \\
\hline Kl.pneumonia isolate 1 & 125 & 250 & 500 & 1000 \\
\hline Kl.pneumonia isolate 2 & 125 & 250 & 500 & 1000 \\
\hline Kl.pneumonia isolate 3 & 250 & 250 & 250 & 2000 \\
\hline Kl.pneumonia isolate 4 & 125 & 250 & 500 & 2000 \\
\hline Kl.pneumonia isolate 5 & 250 & 250 & 500 & 1000 \\
\hline Kl.pneumonia isolate 6 & 250 & 250 & 500 & 2000 \\
\hline Kl.pneumonia isolate 7 & 250 & 250 & 500 & 2000 \\
\hline Kl.pneumonia isolate 8 & 125 & 250 & 250 & 1000 \\
\hline Kl.pneumonia isolate 9 & 250 & 250 & 500 & 2000 \\
\hline Kl.pneumonia isolate 10 & 125 & 500 & 250 & 2000 \\
\hline Kl.pneumonia isolate11 & 250 & 250 & 500 & 1000 \\
\hline Kl.pneumonia isolate 12 & 125 & 500 & 500 & 10000 \\
\hline S. aureus isolate 1 & 62.5 & 125 & 250 & 500 \\
\hline S. aureus isolate 2 & 31.25 & 125 & 250 & 1000 \\
\hline S. aureus isolate 3 & 31.25 & 125 & 250 & 500 \\
\hline S. aureus isolate 4 & 31.25 & 125 & 250 & 1000 \\
\hline S. aureus isolate 5 & 62.5 & 125 & 250 & 1000 \\
\hline S. aureus isolate 6 & 31.25 & 125 & 250 & 1000 \\
\hline S. aureus isolate 7 & 31.25 & 125 & 250 & 1000 \\
\hline S. aureus isolate 8 & 31.25 & 125 & 250 & 1000 \\
\hline S. aureus isolate 9 & 62.5 & 125 & 250 & 1000 \\
\hline S. aureus isolate 10 & 31.25 & 125 & 250 & 500 \\
\hline S. aureus isolate 11 & 31.25 & 125 & 250 & 1000 \\
\hline S. aureus isolate 12 & 31.25 & 125 & 250 & 1000 \\
\hline S. aureus isolate 13 & 31.25 & 125 & 500 & 1000 \\
\hline S. aureus isolate 14 & 31.25 & 125 & 500 & 1000 \\
\hline S. aureus isolate 15 & 31.25 & 125 & 250 & 500 \\
\hline S. aureus isolate 16 & 31.25 & 62.5 & 500 & 1000 \\
\hline S. aureus isolate 17 & 31.25 & 62.5 & 500 & 1000 \\
\hline S. aureus isolate 18 & 31.25 & 62.5 & 250 & 1000 \\
\hline E. coli isolate 1 & 31.25 & 125 & 250 & 500 \\
\hline E. coli isolate 2 & 31.25 & 125 & 500 & 1000 \\
\hline E. coli isolate 3 & 31.25 & 125 & 250 & 500 \\
\hline E. coli isolate 4 & 31.25 & 250 & 250 & 1000 \\
\hline E. coli isolate 5 & 31.25 & 125 & 500 & 1000 \\
\hline E. coli isolate 6 & 31.25 & 125 & 500 & 1000 \\
\hline E. coli isolate 7 & 62.5 & 250 & 500 & 1000 \\
\hline E. coli isolate 8 & 62.5 & 250 & 500 & 1000 \\
\hline E. coli isolate 9 & 62.5 & 250 & 500 & 1000 \\
\hline E. coli isolate 10 & 62.5 & 250 & 500 & 1000 \\
\hline
\end{tabular}




\section{Results}

\subsection{Isolated Bacteria}

The 40 selected isolates were distributed as following: 12 Klebseilla pneumonia, 18 Staphylococcus aureus, and 10 Escherichia coli.

\subsection{Biofilm Mass}

All test strains formed biofilms were detected by the crystal violet assay. The most substantial biofilms were produced by Klebseilla pneumonia isolate no 1, 4, 5, 6, 7 as shown in figure 1 (C4, C9, D8, F1, F8) respectively.

3.3 Minimum Inhibitory Concentration (MIC), Minimum Bactericidal Concentration (MBC), Minimum Biofilm Inhibitory Concentration (MBIC) and Minimum Biofilm Eradication Concentration (MBEC)

In this experiment the ethanol extract of leaves of Malva parviflora was tested for the inhibitory effect against growth of planktonic bacteria of clinical pathogens.

The potency was quantitatively assessed by the MIC, MBC, MBIC and MBEC as presented in Table 1 and qualitatively assessed MBIC and MBEC by crystal violet as shown figure 2 .

The results revealed that MIC and MBC of leaves extract of Malva parviflora ranged from (125-250 mg), (250$500 \mathrm{mg}$ ) respectively for Klebseilla pneumonia while in case of Staphylococcus aureus it was (31.25-62.5 mg), (62.5-125 mg) respectively and with $E$. coli it was (31.25-62.5 mg), (125-250 mg) respectively.

Also, the MBIC and MBEC ranged from (250-500mg), (1000-2000 mg) respectively for Klebseilla pneumonia while in case of Staphylococcus aureus and E. coli it was (250-500 mg), (500-1000 mg) and (250-500 mg), (500$1000 \mathrm{mg}$ ) respectively.

\section{Discussion}

Biofilms are robust communities of microbes that are held by extracellular matrix . They can form on almost any surface where they can potentially cause disease or contaminate medical devices. Due to the numerous challenges of biofilms to health care, there is a continuous need to search for new antimicrobial compounds that can handle incidences and re-infection that could arise from biofilm contaminated medical devices (Adesina et al., 2015).

Herbal drugs have received greater attention in recent times because of their diversity of curing diseases, safety and being well tolerated remedies when compared to the conventional medicines. Biofilm infections represent a serious health threats worldwide today mostly due to the appearance of antibiotic resistant strains. Contemporary testing on MIC which measures only planktonic susceptibility may be the possible explanation for treatment failures and resistant development among bacterial biofilms (Perumal \& Mahmud, 2013).

In the present study, the results of the MIC, MBC, MBIC and MBEC have highlighted the interesting activity of ethanol extract of leaves of Malva parviflora leaf extracts against Klebseilla pneumonia, Staphylococcus aureus and E. coli.

Medicinal plants are rich of secondary metabolites which some of them are directly involved in plant defense mechanisms against microorganisms (Cowan, 1999).

To begin our investigation on antibacterial and antibiofilm activities, the growth inhibition effect of ethanol extract of leaves of Malva parviflora was determined first on planktonic cultures of resistant clinical isolates. Ethanol extract of leaves of Malva parivflora exhibited broad antibacterial spectrum against gram positive and gram negative tested. The difference in susceptibility between gram negative and gram positive may be due to different cell wall composition according to (Fennel et al., 2004) Gram positive bacteria are often found to be more susceptible to plant extracts than the Gram negative bacteria. It is well known that the outer membrane present only in the Gram negative bacteria play an important role as an effective barrier.

Ethanol extract of leaves of Malva parviflora displayed distinct bactericidal mode of action against most of the bacteria tested. The bactericidal activity is confirmed by the obtained MBC values which are usually two to four higher than the corresponding MICs.

Ethanol extract of leaves of Malva parviflora showed antimicrobial activity against gram negative and gram positive bacteria. This finding agree with (Islam et al., 2010; Miri et al., 2013; Kalayou et al., 2012; Ododo et al., 2016).

Ethanol extract of leaves of Malva parviflora exhibited antibiofilm activity against all resistant isolates. The MBEC was 4 times that of planktonic bacteria This is consistent with previous reports indicating that bacteria in biofilms are more resistant to antibiotics and chemical agents than planktonic cells in suspension (Stewart, 2001). 
The increase in MBIC and MBEC due to bacteria living as biofilm are often difficult to eradicate compared to the planktonic mode of growth. Planktonic cells forms biofilms by adhering to each other strongly via formation of pili (Permaul \& Mahud, 2013).

Antibiofilm effect may be due to presence of $2 \mathrm{~S}$ albumin proteins (Salas et al., 2015), these proteins have the characteristic molecular weight, cationic residues, and disulfide bonds of antimicrobial peptides (Nawrot et al., 2014). Antimicrobial peptides kill pathogens by interaction with phospholipids and membrane permeabilization (Nawrot et al., 2014). Also , antibiofilm effect may be due to the presence of $\beta$-sitosterol (Ododo et al., 2016; Abdel-Ghani et al., 2013) which is a natural product found in the cells and membranes of all oil-producing plants, fruit, vegetables, grains, seeds and trees (Sen et al.,2012). Leaves of Malva parviflora were reported to contain $\beta$ sitosterol which has been proven to be a safe, nontoxic, effective nutritional supplement and has amazing potential health benefits in many diverse applications including antibacterial activity (Sen et al., 2012).

Also, leaves of Malva parviflora contains gallic acid (Ereifej et al., 2015) and it was reported that gallic acid has antibiofilm activity against Staphylococcus aureus (Liu et al., 2017).

In conclusion, based on the obtained result ethanol extract of leaves of Malva parviflora may provide a new gate for treatment of biofilm related infections. The antibiofilm activities of the studied plant need more investigation as this is preliminary work.

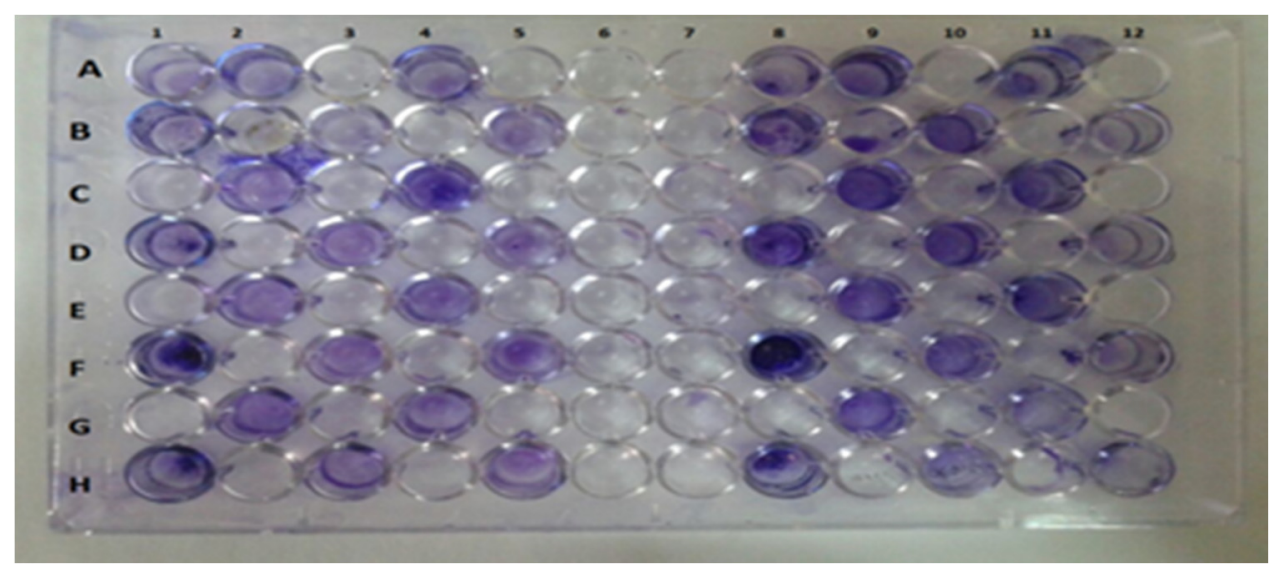

Figure 1. Crystal violet stained biofilm of Klebseilla pneumonia .The most substantial biofilms were produced by Klebseilla pneumonia ( $\mathrm{C} 4, \mathrm{C} 9, \mathrm{D} 8, \mathrm{~F} 1, \mathrm{~F} 8)$ respectively

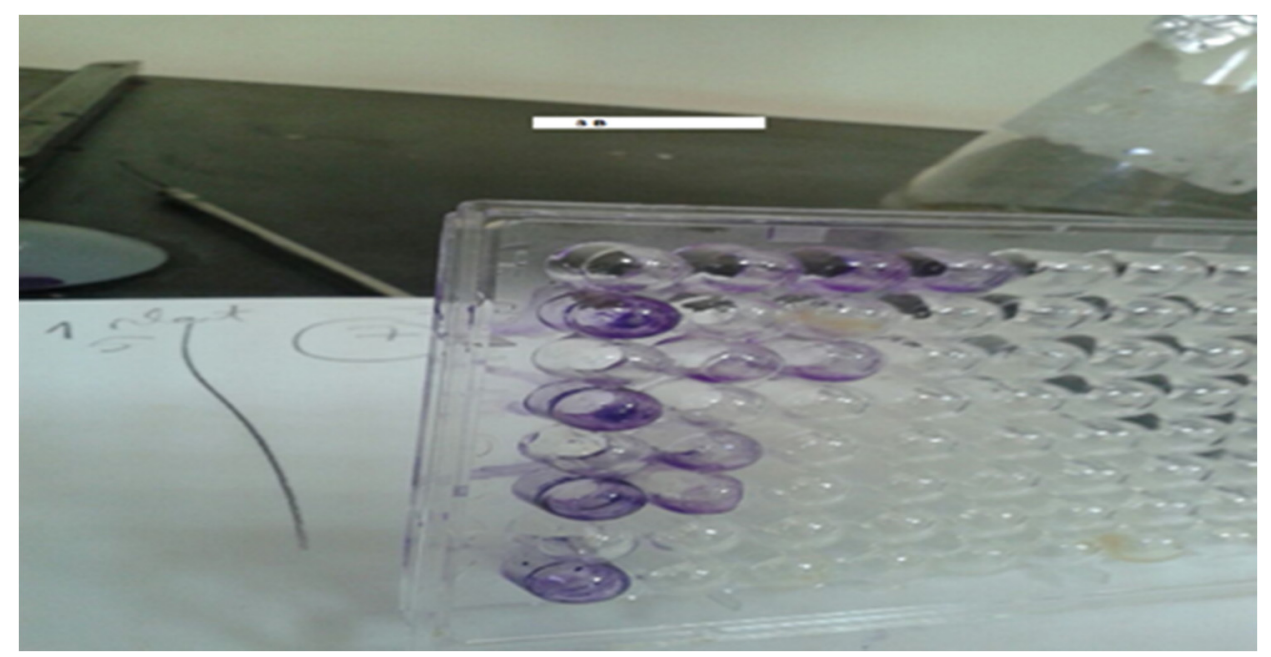

Figure 2. Qualitive determination MBIC and MBEC by crystal violet of biofilm of Klebseilla pneumonia after addition of ethanol extract of leaves of Malva parviflora 


\section{Acknowledgments}

Authors would like to thank Mrs Nurah Ayed Alrashedy, Buraydah Private College for their technical support in Microbiology laboratory.

\section{References}

Abad, M. J., Ansuategui, M., \& Bermejo, P. (2007). Active antifungal substances from natural sources. Arkivoc, 2, 116-145. http://dx.doi.org/10.3998/ark.5550190.0008.711

Abdel-Ghani, A., Hassan, H., \& El-Shazly, A. (2013). Phytochemical and biological study of Malva parviflora L. grown in Egypt. Zagazig J. Pharm. Sci., 22(1), 17-25.

Adesina, T. D., Nwinyi, O. C., \& Olugbuyiro, J. A. (2015). Prevention of Bacterial Biofilms Formation on Urinary Catheter by Selected Plant Extracts. Pakistan journal of biological sciences: PJBS, 18(2), 67-73. Retrieved from https://scialert.net/abstract/?doi=pjbs.2015.67.73

Boulos, L. (2005). Flora of egypt (Vol. 4, pp. 93-95). Cairo: Al Hadara Publishing. https://doi.org/10.1111/j.17561051.1999.tb01119.x

Chaudhary S. (1999-2001). Flora of the Kingdom of Saudi Arabia (pp. 104-203, 255-241, 626-678). Vols. I-III. Riyadh: Ministry of Agriculture and Water Press.

Clardy, J., \& Walsh, C. (2004). Lessons from natural molecules. Nature, 432, 829-837. https://doi.org/10.1038/ nature03194

Cos, P., Vlietinck, A. J., Berghe, D. V., \& Maes, L. (2006). Anti-infective potential of natural products: how to develop a stronger in vitro 'proof-of-concept'. Journal of ethnopharmacology, 106(3), 290-302. https://doi.org/10.1016/j.jep.2006.04.003

Cowan, M. M. (1999). Plant products as antimicrobial agents. Clin Microbiol Rev, 12, 564-582.

de la Fuente-Núñez, C., Reffuveille, F., Fernández, L., \& Hancock, R. E. (2013). Bacterial biofilm development as a multicellular adaptation: antibiotic resistance and new therapeutic strategies. Current opinion in microbiology, 16(5), 580-589. http://dx.doi.org/10.1016/j.mib.2013.06.013.

Deighton, M. A., Capstick, J., Domalewski, E., \& Van Nguyen, T. (2001). [17] Methods for studying biofilms produced by staphylococcus epidermidis. In Methods in enzymology (Vol. 336, pp. 177-195). Academic Press. https://doi.org/10.1016/S0076-6879(01)36589-8

Eloff, J. N. (1998). A sensitive and quick microplate method to determine the minimal inhibitory concentration of plant extracts for bacteria. Planta medica, 64(08), 711-713. http://dx.doi.org/10.1055/s-2006-957563

Ereifej, K. I., Feng, H., Rababah, T., Almajwal, A., Alu'datt, M., Gammoh, S. I., \& Oweis, L. I. (2015). Chemical composition, phenolics, anthocyanins concentration and antioxidant activity of ten wild edible plants. Food and Nutrition Sciences, 6(07), 581. http://dx.doi.org/10.4236/fns.2015.67061

Fennell, C. W., Lindsey, K. L., McGaw, L. J., Sparg, S. G., Stafford, G. I., Elgorashi, E. E., ... \& Van Staden, J. (2004). Assessing African medicinal plants for efficacy and safety: pharmacological screening and toxicology. Journal of ethnopharmacology, 94(2-3), 205-217. https://doi.org/10.1016/j.jep.2004.05.012

Hall-Stoodley, L., Costerton, J. W., \& Stoodley, P. (2004). Bacterial biofilms: from the natural environment to infectious diseases. Nature reviews microbiology, 2(2), 95. http://dx.doi.org/10.1038/nrmicro821

Hengzhuang, W., Wu, H., Ciofu, O., Song, Z., \& Høiby, N. (2011). Pharmacokinetics/pharmacodynamics of colistin and imipenem on mucoid and nonmucoid Pseudomonas aeruginosa biofilms. Antimicrobial agents and chemotherapy, 55(9), 4469-4474. http://dx.doi.org/10.1128/AAC.00126-11

Hengzhuang, W., Wu, H., Ciofu, O., Song, Z., \& Høiby, N. (2012). In vivo pharmacokinetics/pharmacodynamics of colistin and imipenem in Pseudomonas aeruginosa biofilm infection. Antimicrobial agents and chemotherapy, 56(5), 2683-2690.

Høiby, N. (2011). Recent advances in the treatment of Pseudomonas aeruginosa infections in cystic fibrosis. BMC medicine, 9(1), 32. https://doi.org/10.1186/1741-7015-9-32

Høiby, N., Bjarnsholt, T., Givskov, M., Molin, S., \& Ciofu, O. (2010). Antibiotic resistance of bacterial biofilms. $\begin{array}{llll}\text { International journal of antimicrobial } & \text { agents, } 35(4), 332 .\end{array}$ https://doi.org/10.1016/j.jjantimicag.2009.12.011 
Høiby, N., Ciofu, O., Johansen, H. K., Song, Z. J., Moser, C., Jensen, P. Ø., ... \& Bjarnsholt, T. (2011). The clinical impact of bacterial biofilms. International journal of oral science, 3(2), 55. http://dx.doi.org/10.4248/IJOS11026.

Islam, M., Ali, E., Saeed, M. A., Jamshaid, M., \& Khan, M. T. J. (2007). Antimicrobial and Irritant activities of the extracts of Malva Parviflora L., Malvastrum Coromandelianum L. and Amaranthus viridis L.-A Preliminary Investigation. Pakistan Journal of Pharmacy, 2010, 20-23.

Kalayou, S., Haileselassie, M., Gebre-egziabher, G., Tiku'e, T., Sahle, S., Taddele, H., \& Ghezu, M. (2012). Invitro antimicrobial activity screening of some ethnoveterinary medicinal plants traditionally used against mastitis, wound and gastrointestinal tract complication in Tigray Region, Ethiopia. Asian Pacific journal of tropical biomedicine, 2(7), 516-522. http://dx.doi.org/10.1016/S2221-1691(12)60088-4.

Liu, M., Wu, X., Li, J., Liu, L., Zhang, R., Shao, D., \& Du, X. (2017). The specific anti-biofilm effect of gallic acid on Staphylococcus aureus by regulating the expression of the ica operon. Food Control, 73, 613-618. http://dx.doi.org/10.1016/j.foodcont.2016.09.015

Migahid, A. M. (1996). Flora of Saudi Arabia. King Saud Univ. Press.

Miri, A., Rad, J. S., Alfatemi, S. M. H., \& Rad, M. S. (2013). A study of antibacterial potentiality of some plants extracts against multidrug resistant human pathogens. Ann. Biol. Res, 4(8), 35-41.

Nawrot, R., Barylski, J., Nowicki, G., Broniarczyk, J., Buchwald, W., \& Goździcka-Józefiak, A. (2014). Plant antimicrobial peptides. Folia microbiologica, 59(3), 181-196. http://dx.doi.org/10.1007/s12223-013-0280-4

Ododo, M. M., Choudhury, M. K., \& Dekebo, A. H. (2016). Structure elucidation of $\beta$-sitosterol with antibacterial activity from the root bark of Malvaparviflora. SpringerPlus, 5(1), 1210. http://dx.doi.org/10.1186/s40064016-2894-X

Perumal, S., \& Mahmud, R. (2013). Chemical analysis, inhibition of biofilm formation and biofilm eradication potential of Euphorbia hirta L. against clinical isolates and standard strains. BMC complementary and alternative medicine, 13(1), 346. http://dx.doi.org/10.1186/1472-6882-13-346.

Qu, Y., Istivan, T. S., Daley, A. J., Rouch, D. A., \& Deighton, M. A. (2009). Comparison of various antimicrobial agents as catheter lock solutions: preference for ethanol in eradication of coagulase-negative staphylococcal biofilms. Journal of medical microbiology, 58(4), 442-450. http://dx.doi.org/10.1099/jmm.0.006387-0.

Salas, C. E., Badillo-Corona, J. A., Ramírez-Sotelo, G., \& Oliver-Salvador, C. (2015). Biologically active and antimicrobial peptides from plants. BioMed research international, 2015. http://dx.doi.org/10.1155/2015/102129.

Sen, A., Dhavan, P., Shukla, K. K., Singh, S., \& Tejovathi, G. (2012). Analysis of IR, NMR and antimicrobial activity of $\beta$-sitosterol isolated from Momordica charantia. Sci Secure J Biotechnol, 1(1), 9-13.

Stepanović, S., Vuković, D., Dakić, I., Savić, B., \& Švabić-Vlahović, M. (2000). A modified microtiter-plate test for quantification of staphylococcal biofilm formation. Journal of microbiological methods, 40(2), 175-179. https://doi.org/10.1016/S0167-7012(00)00122-6

Stepanović, S., Vuković, D., Hola, V., BONAVENTURA, G. D., Djukić, S., Ćirković, I., \& Ruzicka, F. (2007). Quantification of biofilm in microtiter plates: overview of testing conditions and practical recommendations for assessment of biofilm production by staphylococci. Apmis, 115(8), 891-899. http://dx.doi.org/10.1111/ j.1600-0463.2007.apm_630.x .

Stewart, P. S., Rayner, J., Roe, F., \& Rees, W. M. (2001). Biofilm penetration and disinfection efficacy of alkaline hypochlorite and chlorosulfamates. Journal of applied microbiology, 91(3), 525-532. https://doi.org/10.1046/ j.1365-2672.2001.01413.x

Wu, H., Moser, C., Wang, H. Z., Høiby, N., \& Song, Z. J. (2015). Strategies for combating bacterial biofilm infections. International journal of oral science, 7(1), 1. http://dx.doi.org/10.1038/ijos.2014.65

\section{Copyrights}

Copyright for this article is retained by the author(s), with first publication rights granted to the journal.

This is an open-access article distributed under the terms and conditions of the Creative Commons Attribution license (http://creativecommons.org/licenses/by/4.0/). 